\title{
Application of Ferriferous Oxide Modified by Chitosan in Gene Delivery
}

\author{
Yu Kuang, ${ }^{1}$ Tun Yuan, ${ }^{2}$ Zhongwei Zhang, ${ }^{3}$ Mingyuan Li, ${ }^{1}$ and Yuan Yang1 \\ ${ }^{1}$ West China School of Preclinical and Forensic Medicine, Sichuan University, Chengdu, Sichuan 610041, China \\ ${ }^{2}$ National Engineering Research Center for Biomaterials, Sichuan University, Chengdu, Sichuan 610064, China \\ ${ }^{3}$ ICU of West China Hospital, Sichuan University, Chengdu, Sichuan 610041, China
}

Correspondence should be addressed to Mingyuan Li, lmy3985@sina.com and Yuan Yang, amyyang1114@gmail.com

Received 9 September 2012; Revised 17 December 2012; Accepted 18 December 2012

Academic Editor: R. Pignatello

Copyright ( $) 2012$ Yu Kuang et al. This is an open access article distributed under the Creative Commons Attribution License, which permits unrestricted use, distribution, and reproduction in any medium, provided the original work is properly cited.

\begin{abstract}
New approaches to improve the traditional gene carriers are still required. Here we explore $\mathrm{Fe}_{3} \mathrm{O}_{4}$ modified with degradable polymers that enhances gene delivery and target delivery using permanent magnetic field. Two magnetic $\mathrm{Fe}_{3} \mathrm{O}_{4}$ nanoparticles coated with chitosan (CTS) and polyethylene glycol (PEG) were synthesized by means of controlled chemical coprecipitation. Plasmid pEGFP was encapsulated as a reported gene. The ferriferous oxide complexes were approximately spherical; surface charge of CTS- $\mathrm{Fe}_{3} \mathrm{O}_{4}$ and PEG-Fe ${ }_{3} \mathrm{O}_{4}$ was about $20 \mathrm{mv}$ and $0 \mathrm{mv}$, respectively. The controlled release of DNA from the CTS-Fe $\mathrm{O}_{4}$ nanoparticles was observed. Concurrently, a desired $\mathrm{Fe}_{3} \mathrm{O}_{4}$ concentration of less than $2 \mathrm{mM}$ was verified as safe by means of a cytotoxicity test in vitro. Presence of the permanent magnetic field significantly increased the transfection efficiency. Furthermore, the passive target property and safety of magnetic nanoparticles were also demonstrated in an in vivo test. The novel gene delivery system was proved to be an effective tool required for future target expression and gene therapy in vivo.
\end{abstract}

\section{Introduction}

Nonviral gene vectors have many advantages such as mass production, easier transportation, less immunogenicity, and being easily targeted to organs $[1,2]$. Among the nonviral vectors, chitosan is known to possess efficient properties owing to their ability to condense nucleic acid into stable complexes, which protects DNA from degradation by nuclease [3]. The DNA/polymer complexes are taken up into the cells via endocytosis into the endosomes [4], following with burst release of complexes fraction in endosomes and the DNA translocates into the nucleus. Chitosan is copolymer of $\mathrm{N}$-acetyl-glucosamine and glucosamine. It is soluble at acidic $\mathrm{PH}$ value, and the amino groups carry positive charge in acidic mediums; it can combine with negatively charged DNA. Moreover, chitosan also easily associates with iron oxide nanoparticles. It has been used generally in pharmaceutical applications [5]. Previous studies have revealed that chitosan, like other cationic polymers, displayed concentration-dependent toxicity toward cells in vitro, although it had many advantages as a gene vector [6].
Magnetic ferriferous oxide nanoparticles possess prominent advantages that might correct the defects of traditional drugs and gene carriers. They possess both magnetic and nanoeffects [7]. Whereby numerous DNA strands attached to the surface of these ferriferous oxides could reach the desired position with the help of static magnetic field. In order to improve the properties of nanoparticles such as biocompatibility, transfection efficiency, and controlled release, we embedded the biodegradable polymers on the surface of ferriferous oxide to form a core shell structure [8]. Therefore, the focus of our research was on how to improve the target property and remove the application barriers of nonviral gene vectors in vivo. The use of a static magnetic field has been shown to result in dramatic increase in transfection efficiency of gene delivery when compared with the conventional transfection system $[9,10]$. Magnetassisted transfection is a new, easy-to-handle, very highly efficient technology. It is a very gentle method with almost no toxicity and has been successfully used on many and also critical cell lines [11]. All types of nucleic acids from plasmid DNA or oligonucleotides to siRNA can be used 
with this approach [12]. In this research, the synthesized magnetic nanoparticles have an approximately size of $100 \mathrm{~nm}$ and are additionally coated with biodegradable polymers. We used both of the advantages of magnetic nanoparticles and biodegradable polymers, and the application of the novel polymer- $\mathrm{Fe}_{3} \mathrm{O}_{4}$ complexes as gene vectors in vitro was then described at length.

\section{Materials and Methods}

2.1. Preparation of Polymer-Fe $\mathrm{O}_{4}$ Nanoparticles. The magnetic nanoparticles used as gene carriers are mostly iron oxides. These iron oxides can be generated by precipitation from acidic iron-salt solutions upon addition of appropriate bases [13]. Aqueous dispersions of $\mathrm{Fe}_{3} \mathrm{O}_{4}$ coated with polymers were prepared as latter. A CTS (MWs $45 \mathrm{kDa}, 20 \%$ w/w, pH6.9) solution carrying a positive charge or PEG (MWs $6 \mathrm{kDa}, 20 \% \mathrm{w} / \mathrm{w}$ ) solution was prepared. $0.2 \mathrm{~mL}$ of this solution was added to $0.8 \mathrm{~mL}$ of iron oxide dispersion $(10 \% \mathrm{w} / \mathrm{w})$ for $8 \mathrm{~h}$ incubation. After filtration sterilization with a $0.45 \mu \mathrm{m}$ filter, the nanoparticles were used for the next transfection experiments. Nanoparticles and DNA form complexes by ionic interaction of the negatively charged nucleic acid and the positively charged surface of the CTS- $\mathrm{Fe}_{3} \mathrm{O}_{4}$ nanoparticle (N/P ratio 4:1). The polymer$\mathrm{Fe}_{3} \mathrm{O}_{4}$ was analyzed by means of a transmission electron microscope (TEM, HITACHI H-700H), X-ray diffraction (XRD, Philips X'Pert PRO). The size and zeta potential of the polymer- $\mathrm{Fe}_{3} \mathrm{O}_{4}$ were both assessed using the Zetasizer Nano instrument.

2.2. Assay of DNA Encapsulation Efficiency. EGFP was used to monitor gene transfer and gene expression after transfection. The plasmid pEGFP-C1 was propagated in Escherichia coli and was purified using an Endotoxin-free Plasmid Maxiprep Kit (Qiagen). At the $\mathrm{pH}$ level of 7.4 the polymer- $\mathrm{Fe}_{3} \mathrm{O}_{4}$ complexes were mixed with DNA at different volume ratios in a $50 \mu \mathrm{L}$ reaction system. The final concentration (FC) of plasmid DNA and polymer $\mathrm{Fe}_{3} \mathrm{O}_{4}$ was $4 \mu \mathrm{g} / \mu \mathrm{L}$ and $1 \mathrm{mM}$ (concentrations related to $\mathrm{Fe}$ ) diluted with doubledistilled water $\left(\mathrm{ddH}_{2} \mathrm{O}\right)$. After $1 \mathrm{~h}$ incubation at $37^{\circ} \mathrm{C}$ the concentration of DNA in the supernatant was measured by UV spectrophotometric absorption at $260 \mathrm{~nm}$. The encapsulation efficiency (E.E.) of the process indicates the percentage of DNA encapsulated used for the preparation of polymer$\mathrm{Fe}_{3} \mathrm{O}_{4}$ complexes.

2.3. Target Distribution of Polymer $\mathrm{Fe}_{3} \mathrm{O}_{4}$. To observe the target distribution of polymer- $\mathrm{Fe}_{3} \mathrm{O}_{4}$ nanoparticles in different organs of mice, 40 pathogen-free BALB/c female mice were purchased from the Sichuan Industrial Institute of Antibiotic for the in vivo studies. The polymer $\mathrm{Fe}_{3} \mathrm{O}_{4}$ was redispersed as described previously and injected through the caudal vein on the dosage of $1 \mathrm{mM}$ iron oxide in $0.8 \mathrm{~mL}$. A neodymiumiron-boron $(\mathrm{NdFeB})$ permanent magnet $(\mathrm{Br} 1 / 41.5 \mathrm{~T})$ was fixed to the surface of the extrahepatic skin for 6 hours. The mice were sacrificed at different times after the injection $(2 \mathrm{~h}$, $6 \mathrm{~h}, 12$, and $24 \mathrm{~h}$ ), and the liver, spleen, lungs, heart, and brain were taken out and made into tissue slices. The target distribution of polymer $\mathrm{Fe}_{3} \mathrm{O}_{4}$ was observed by Prussian blue and neutral red staining.

2.4. In Vitro Release. Release kinetics of plasmid DNA from magnetic nanoparticles were studied [14]. For this experiment, preweighed polymer- $\mathrm{Fe}_{3} \mathrm{O}_{4}$ complexes containing DNA were incubated in a test tube with phosphatebuffered saline (PBS, pH 7.4), for $30 \mathrm{~min}$ under moderate stirring at $37^{\circ} \mathrm{C}$. DNA was reacted with polymer- $\mathrm{Fe}_{3} \mathrm{O}_{4}$ nanoparticles at three different volume ratios $(1: 3,1: 1$, and $3: 1)$. At predetermined time intervals $(12,24,48,72$, and $96 \mathrm{~h}), 50 \mu \mathrm{L}$ of the released medium was collected by centrifugation $(3,000 \times \mathrm{g}, 1 \mathrm{~min})$, and $50 \mu \mathrm{L}$ of fresh PBS was added back into the test tube. DNA release was monitored by UV spectroscopy at $260 \mathrm{~nm}$, and DNA integrity was evaluated on a $1 \%$ agarose gel. The amount of released DNA was calculated from the free DNA concentration in the supernatants, and the curve of DNA release in vitro was described. At last, to confirm the functionality of released DNA, the discharged DNA was applied to the assay of transfection in vitro.

2.5. Test of DNaseI Treatment. The polymer- $\mathrm{Fe}_{3} \mathrm{O}_{4}$ complexes $(1 \mathrm{mM})$ were mixed with plasmid DNA $(4 \mu \mathrm{g} / \mu \mathrm{L})$ according to the optimal E.E. Naked plasmid DNA and DNA/polymer- $\mathrm{Fe}_{3} \mathrm{O}_{4}$ complexes were incubated with or without DNaseI $(0.5 \mathrm{U})$ in the $30 \mu \mathrm{L}$ reaction system for 1 hour at $\mathrm{pH}$ 7.4. The digestion was stopped by addition of $0.5 \mathrm{M}$ EDTA. The product of enzymatic digestion was analyzed by $1 \%$ agarose gel electrophoresis, and DNA in the gel was visualized by ethidium bromide staining. Naked plasmid DNA after being digested by DNaseI and naked plasmid DNA without digestion were used as controls.

2.6. Cell Culture and Cell Viability Assay. Human Embryonic Kidney 293 cells (HEK-293), human liver carcinoma cells (HepG2), and mouse myeloma cell line (SP2/0) were maintained in DMEM or RPMI-1640 medium (GibcoBRL), supplemented with 10\% fetal calf serum (FCS, GibcoBRL) and $1 \%$ penicillin/streptomycin. For the transfection and cytotoxicity test, the cells were grown under standard conditions for 24 hours until $70 \%$ to $80 \%$ confluency in $96-$ well flat-bottomed microassay plates before the addition of either the plasmid DNA/polymer- $\mathrm{Fe}_{3} \mathrm{O}_{4}$ complex or only the polymer $\mathrm{Fe}_{3} \mathrm{O}_{4}$.

Assessment of cell viability was performed by the MTT assay. Firstly, the precipitate polymer- $\mathrm{Fe}_{3} \mathrm{O}_{4}$ complexes were resuspended under conditions of ultrasonic agitation for $10 \mathrm{~min}$. Subsequently, the complexes were added into the cell-culture fluid at a different concentration $(0.2 \sim 1.0 \mathrm{mM}$, $2 \sim 20 \mathrm{mM})$, diluted with a serum-free medium. At the end of each predetermined time $(6 \mathrm{~h}, 12 \mathrm{~h}, 24 \mathrm{~h}$, and $48 \mathrm{~h})$, the polymer- $\mathrm{Fe}_{3} \mathrm{O}_{4}$ complexes were replaced with $200 \mu \mathrm{L}$ of fresh DMEM medium. Then, $20 \mu \mathrm{L}$ of MTT $(5 \mu \mathrm{g} / \mu \mathrm{L})$ in DMEM was added to each well and incubated for an additional 4 hours. All mediums were then removed, and $150 \mu \mathrm{L}$ of DMSO was added to dissolve the crystals formed by the live 
cells. Absorbance was measured at $570 \mathrm{~nm}$ using a Bio-Tek EL-311microplate reader. The cell viability was calculated, and the viability of nontreated control cells was arbitrarily defined as $100 \%$.

2.7. Magnet-Assisted Transfection In Vitro. 24-well plates were seeded with $2 \times 10^{5}$ cells (HepG2 and SP2/0 cells) and grown for 24 hours to obtain $70-80 \%$ confluence. Prior to transfection, the medium was removed, and the cells were rinsed once with PBS ( $\mathrm{pH}$ 7.4), then supplied with serum-free medium. The plasmid DNA was mixed with CTS$\mathrm{Fe}_{3} \mathrm{O}_{4}$ and PEG- $\mathrm{Fe}_{3} \mathrm{O}_{4}$ as described previously and incubated for 30 minutes at $37^{\circ} \mathrm{C}$. DNA/polymer- $\mathrm{Fe}_{3} \mathrm{O}_{4}$ complexes were suspended in a serum-free medium to get the final concentrations of $2 \mu \mathrm{g} / \mu \mathrm{L}$ and $1.5 \mathrm{mM}$, respectively. To verify the short exposure to a static magnetic field would improve transfection efficiency; the cells were placed on a $(\mathrm{NdFeB})$ magnet for $30 \mathrm{~min}$ at a distance of $3 \mathrm{~mm}$ from the magnet surface, which leads to a magnetic flux density of $340 \mathrm{mT}$ and a magnetic field gradient perpendicular to the well plate of $14 \mathrm{~T} / \mathrm{m}$. After a further incubation of $4 \mathrm{~h}$, the medium was removed and a new medium containing $10 \%$ FCS was added. The cells were incubated with plasmid DNA alone and DNA/polymer- $\mathrm{Fe}_{3} \mathrm{O}_{4}$ complexes under standard conditions and grown in culture medium for 24 hours to allow for EGFP expression. Concurrently, transfection was performed using nonmagnetic transfection reagents. Chitosan (MWs $45 \mathrm{kDa}$ ), lipofectamine (BestBio), and PBS were added to an equal volume of DNA as controls. Transfected cells expressing green fluorescent protein were detected using a Leica fluorescence microscope.

\section{Results and Discussion}

3.1. Characteristics of Polymer-Fe ${ }_{3} \mathrm{O}_{4}$ Nanoparticles. TEM images showed that most of the iron oxide complexes were approximately spherical (unpublished data). The XRD measurements also indicated that the samples had a cubic crystal system and magnetite $\mathrm{Fe}_{3} \mathrm{O}_{4}$ was the dominant body of the polymer- $\mathrm{Fe}_{3} \mathrm{O}_{4}$ complexes. The size and zeta potential showed the two samples to have a uniform size of $100 \mathrm{~nm}$ (Figure 1(a)) and almost the same distribution. The sizes of $10-100 \mathrm{~nm}$ in diameter are desirable since they are too small not to be eliminated by the reticuloendothelial system (RES) but too large to be filtered out by the kidneys [15]. CTS$\mathrm{Fe}_{3} \mathrm{O}_{4}$ had a positive charge of about $20 \mathrm{mv}$ (Figure 1(b)), and the zeta potential of PEG- $\mathrm{Fe}_{3} \mathrm{O}_{4}$ was $0 \mathrm{mv}$. It has been reported that surface charge plays an important role in determining the efficiency and mechanism of cellular uptake [16]. It is also an important factor to improve stability of polymer- $\mathrm{Fe}_{3} \mathrm{O}_{4}$ complexes and to prevent from further aggregation in aqueous solution via electrostatic repulsion [17]. Zata potential value showed the main binding ability between the polymer $\mathrm{Fe}_{3} \mathrm{O}_{4}$ and DNA. The polymer- $\mathrm{Fe}_{3} \mathrm{O}_{4}$ complexes were mixed with plasmid DNA according to different volume ratios $(1: 3,1: 2,1: 1,2: 1$, and $3: 1)$ in a $50 \mu \mathrm{L}$ reaction system. It was obvious that the E.E. increased along with the proportion of the magnetic materials mainly

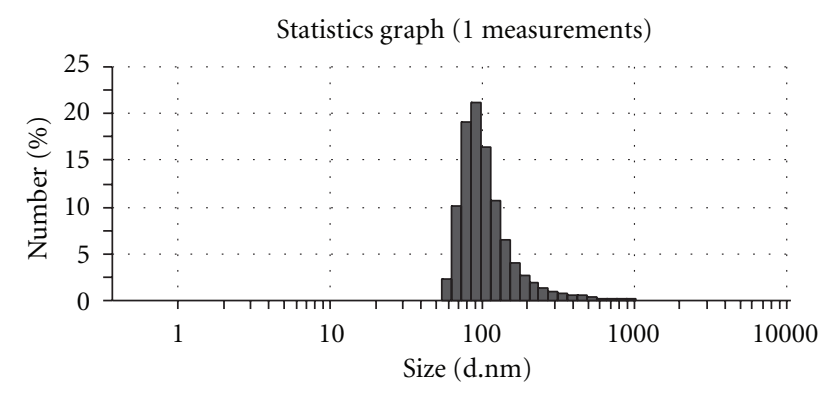

Mean with \pm 1 standard deviation error bar

(a)

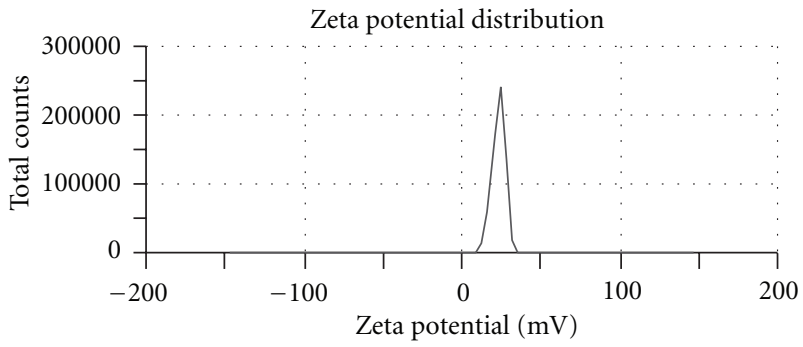

(b)

Figure 1: The size and zeta potential of the CTS-Fe $\mathrm{O}_{4}$. (a) Size of distribution of the CTS- $\mathrm{Fe}_{3} \mathrm{O}_{4}$; (b) zeta potential of the CTS- $\mathrm{Fe}_{3} \mathrm{O}_{4}$.

because of the electrostatic interactions, surface energy of nanoparticles, and branched structures of polymers. The optimal E.E emerged when the iron oxide complexes were mixed with DNA at $3: 1$ volume ratio, and the final concentration of DNA and iron oxide was $2 \mu \mathrm{g} / \mu \mathrm{L}$ and $1.5 \mathrm{mM}$ respectively. The concentration corresponded with the transfection and cell viability assay latter. In addition, the E.E. of PEG- $\mathrm{Fe}_{3} \mathrm{O}_{4}$ was inferior to CTS- $\mathrm{Fe}_{3} \mathrm{O}_{4}$ notably for the lack of electrostatic attraction.

3.2. Target Distribution In Vivo. The different organs from the mice injected with polymer- $\mathrm{Fe}_{3} \mathrm{O}_{4}$ were taken out and made into tissue slices. Target distribution of polymer $\mathrm{Fe}_{3} \mathrm{O}_{4}$ in vivo was demonstrated with the help of outer static magnetic field. Figure 2(b) shows a large number of iron particles scattered in the hepatic tissue; many of them were distributed along the hepatic sinusoid $2 \mathrm{~h}$ after injection. The iron particles decreased gradually over time and disappeared $24 \mathrm{~h}$ after injection (data not shown). The shape of the liver cells was seen under a high-power microscope to be integrated. There was no iron staining in the other organs, such as the lungs (Figure 2(d)), the spleen, and the heart. And there was no obvious side effect observed in the injected mice.

3.3. Test of Polymer-Fe $\mathrm{O}_{3} \mathrm{O}_{4}$-Loaded DNA In Vitro. Protection of DNA from DNaseI degradation was detected by $1 \%$ agarose gel electrophoresis. Naked pEGFP-C1 without digestion and naked pEGFP-C1 following digestion by DNaseI were used as controls. We could evidence partial protection 


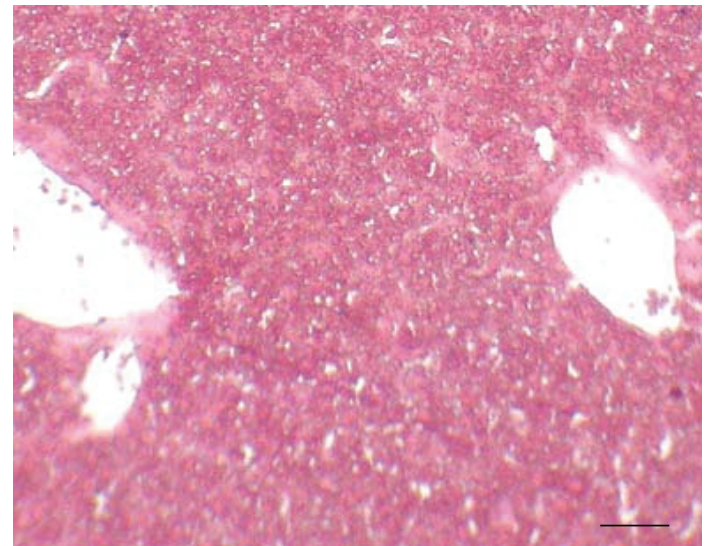

(a)

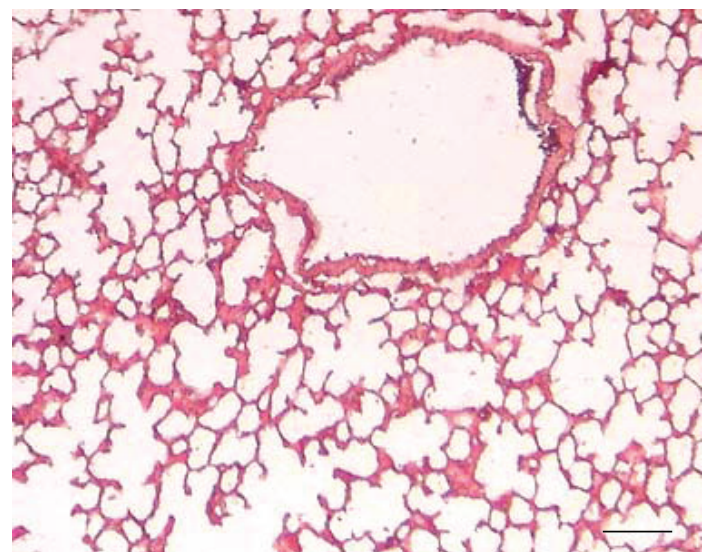

(c)

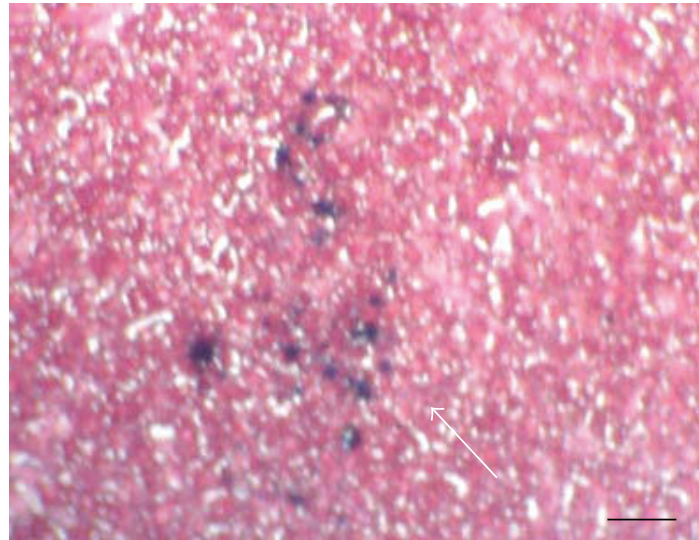

(b)

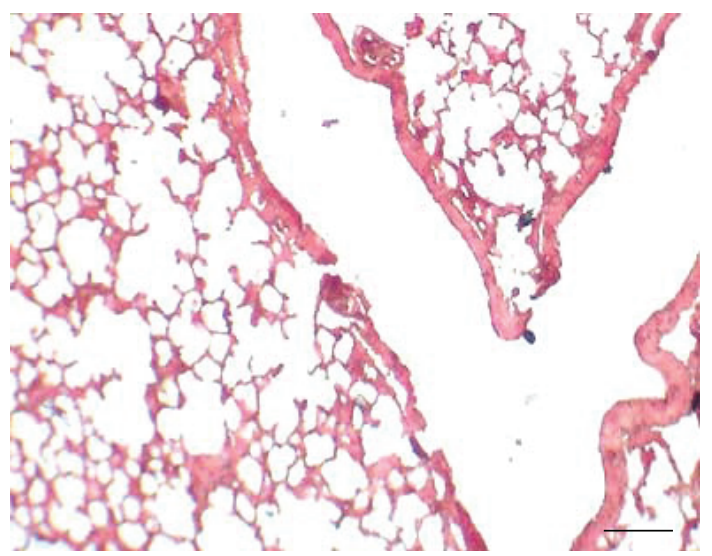

(d)

FIgURE 2: Target distribution of magnetic CTS- $\mathrm{Fe}_{3} \mathrm{O}_{4}$ in liver and lung tissue. Figures were shown by Prussian blue and neutral red staining ( $\times 250$ ), with outer static magnetic field for 2 hours. (a) Normal liver tissue; (b) liver tissue injected CTS-Fe $\mathrm{O}_{4}$ nanoparticles (1 mM); (c) normal lung tissue; (d) lung tissue injected CTS- $\mathrm{Fe}_{3} \mathrm{O}_{4}$ nanoparticles $(1 \mathrm{mM})$. Scale bars correspond to $10 \mu \mathrm{m}$.

of DNA coated by polymer $\mathrm{Fe}_{3} \mathrm{O}_{4}$ from nuclease-mediated DNA degradation (unpublished data). It was assumed that DNA degradation occurs in several layers; external layers will be degraded easily but not internal layers. Furthermore, CTS- $\mathrm{Fe}_{3} \mathrm{O}_{4}$ nanoparticles offered higher protection for DNA than $\mathrm{PEG}-\mathrm{Fe}_{3} \mathrm{O}_{4}$, as the DNA chains could be attached more strongly to the former. In addition, DNaseI digestion resulted in a shift in the most distribution of the DNA isoforms: supercoiled plasmid in nontreated samples was replaced by the open loop form in treated samples.

The in vitro release rates of DNA from polymer- $\mathrm{Fe}_{3} \mathrm{O}_{4}$ complexes were studied at different volume ratios. A significant proportion $(30 \%)$ of the adsorbed DNA was released very rapidly from the CTS- $\mathrm{Fe}_{3} \mathrm{O}_{4}$ nanoparticles in the initial 12 hours. After $48 \mathrm{~h}$, the amount of released DNA reached $55 \%$ at the optimal E.E. And the remainder of the adsorbed DNA was released slowly, reaching $70 \%$ at $96 \mathrm{~h}$ (Figure $3(\mathrm{a})$ ). Compared to DNA release from CTS- $\mathrm{Fe}_{3} \mathrm{O}_{4}$, a burst release phase of more than $61 \%$ from $\mathrm{PEG}-\mathrm{Fe}_{3} \mathrm{O}_{4}$ was observed. The release curve showed that the DNA was released more rapidly; more than $80 \%$ of DNA was discharged from PEG-Fe ${ }_{3} \mathrm{O}_{4}$ after $24 \mathrm{~h}$ at the optimal E.E., and the entire release was mostly completed at $72 \mathrm{~h}$ (Figure $3(\mathrm{~b})$ ). The DNA integrity test at predetermined time points was assessed by agarose gel electrophoresis (data not shown). No differences were observed between EGFP expression from the released DNA and the controlled plasmid pEGFP-C1, indicating that adsorption and release from the polymer- $\mathrm{Fe}_{3} \mathrm{O}_{4}$ do not alter the functionality of plasmid DNA. Overall, the controlled release effect of CTS- $\mathrm{Fe}_{3} \mathrm{O}_{4}$ complexes was relatively obvious compared with $\mathrm{PEG}-\mathrm{Fe}_{3} \mathrm{O}_{4}$. The speed of DNA release was inversely proportional to the volume ratios of nanoparticles.

The N/P ratio (the ratio of negatively charged DNA to positively charged chitosan) is a key factor to determine the optimal complexation conditions. The difference $\mathrm{PH}$ and counterions in the medium might directly affect the binding between CTS and DNA [18]. It could be inferred that the burst release was induced by the DNA degradation in the external layers. The results showed that the controlledrelease effect of $\mathrm{CTS}-\mathrm{Fe}_{3} \mathrm{O}_{4}$ was more obvious, and the unsteady binding power made the efficient binding with DNA and PEG- $\mathrm{Fe}_{3} \mathrm{O}_{4}$ impossible. In addition, the small proportion of chitosan in the polymer- $\mathrm{Fe}_{3} \mathrm{O}_{4}$ complexes actually hindered the effect of controlled release. Increasing 


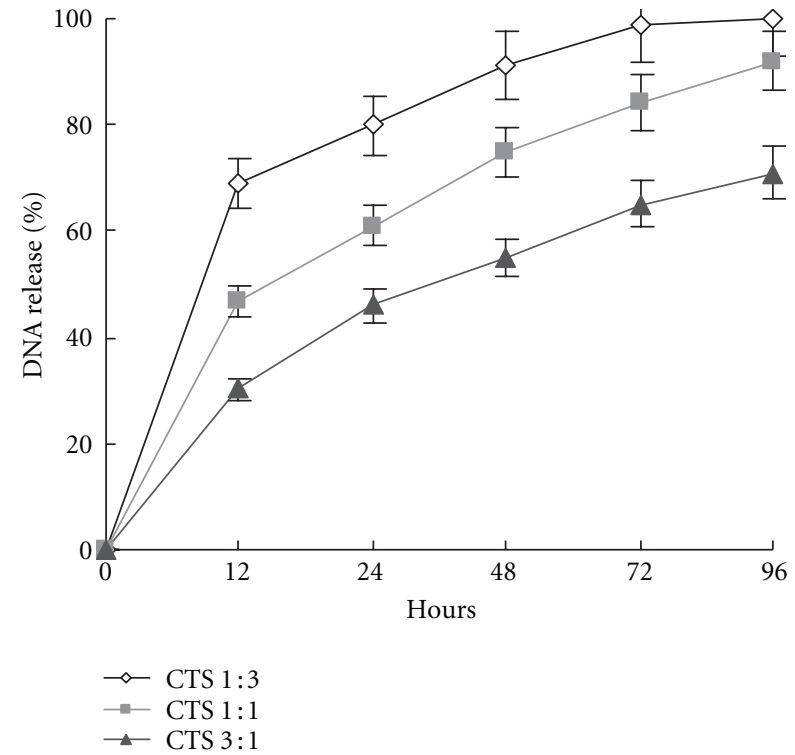

(a)

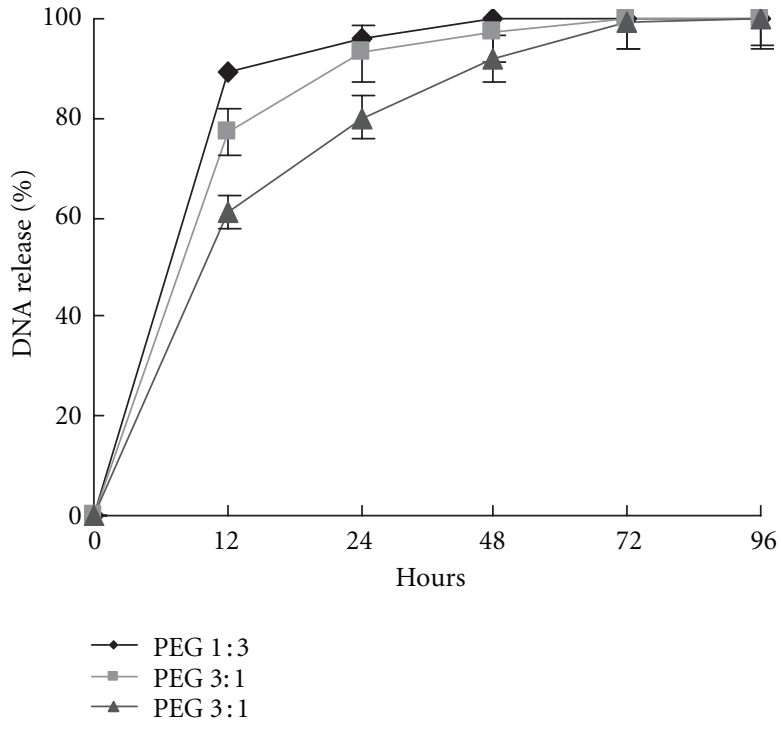

(b)

FIgure 3: Kinetics of DNA release from the magnetic nanoparticles in vitro. (a) Percentage of DNA release coated by CTS-Fe $\mathrm{O}_{4}$ and (b) percentage of DNA release coated by $\mathrm{PEG}-\mathrm{Fe}_{3} \mathrm{O}_{4}$ at $\mathrm{PH}$ 7.4. The data shown are the mean \pm standard deviation for three independent experiments.

the proportion of chitosan would slow down the DNA release but augment the particle size and positive charge of the complexes. It has been reported that positively charged nanoparticles exhibited dose-dependent hemolytic activities and cytotoxicities [19]. In addition, most of the larger nanoparticles $(>150 \mathrm{~nm})$ are trapped by the liver and lung where many macrophages are located [20]. For the drug and gene target delivery application, the nonspecific uptake of nanoparticles by macrophages in the RES should be minimized. The contradictory issue of controlled-release and particle size needs to be resolved urgently by carrying out a further study.

3.4. Cell Viability and Magnet-Assisted Transfection. Low cytotoxicity is one of the major requirements for nonviral vectors for gene delivery. Chitosan was chosen as a functionalizing polysaccharide because of its biocompatibility. It has been reported that chitosan derivatives are less toxic than other cationic polymers such as PEI in vitro and in vivo [21]. Evaluation of cell viability was conducted on HEK-293 and HepG2 cells using a $0.2-20 \mathrm{mM}$ concentration gradient of polymer- $\mathrm{Fe}_{3} \mathrm{O}_{4}$ complexes for different incubation periods. More than $90 \%$ cell viability of both polymer- $-\mathrm{Fe}_{3} \mathrm{O}_{4}$ complexes was obtained after $24 \mathrm{~h}$ of incubation with a concentration of $2 \mathrm{mM}$ or less, and apparent cytotoxicity emerged when the concentration of polymer $\mathrm{Fe}_{3} \mathrm{O}_{4}$ was more than $10 \mathrm{mM}$ (data not shown). This result showed that both CTS- $\mathrm{Fe}_{3} \mathrm{O}_{4}$ and PEG- $\mathrm{Fe}_{3} \mathrm{O}_{4}$ had low cytotoxicity. There was no significant difference in cytotoxicity between the two kinds of magnetic materials. The security application could therefore be deduced according to the previously mentioned data and the optimal E.E.
HepG2 and SP2/0 cells were transfected as described previously with either DNA/CTS- $\mathrm{Fe}_{3} \mathrm{O}_{4}$ or DNA/PEG$\mathrm{Fe}_{3} \mathrm{O}_{4}$, with DNA/chitosan, DNA/lipofectamine, and naked plasmid as controls. Exposure to a permanent magnetic field (magnet) for $30 \mathrm{~min}$ was followed by $4 \mathrm{~h}$ incubation. Concurrently, the control groups were routinely transfected using conventional methods. The highest transfection rates were achieved in HepG2 cells corresponding to $67.2 \%$ and $45.8 \%$ after transfected with $\mathrm{CTS}-\mathrm{Fe}_{3} \mathrm{O}_{4}$ and PEG$\mathrm{Fe}_{3} \mathrm{O}_{4}$ complexes. Significantly lower transfection rates of $14.3 \%, 8.7 \%$, and $0.4 \%$ resulted from transfection with lipofectamine, chitosan, and naked plasmid, respectively. In addition, the transfection rates were significantly increased by 4.1 - and 3.2-fold in HepG2 and SP2/0 cells, when compared to cells not exposed to the magnetic field. Similar transfection results were also obtained with SP2/0 cells, and lower rates of $43.7 \%$ and $32.5 \%$ treated with CTS$\mathrm{Fe}_{3} \mathrm{O}_{4}$ and PEG- $\mathrm{Fe}_{3} \mathrm{O}_{4}$ complexes were achieved. Compared with conventional transfected methods, the results were still statistically significant (Figure 4). Thus, the transfections rates enhanced by the assistance of magnetic field were verified again in HepG2 and SP2/0 cells. It seems that the use of a static magnetic field can improve the translocation of the particles across the cell membrane. It has been reported that the higher transfection rates with magnetic nanoparticles were mainly attributed to their size surface charge, since the larger nanoparticles faster sedimentated on the surfaces of the cells, and this resulted in higher endocytic uptake, and positively charged nanoparticles were more easily taken up by cells [22]. The chosen cells used in our study were malignant cells from human and mice, and these cells differed in characteristics used as models for different human 


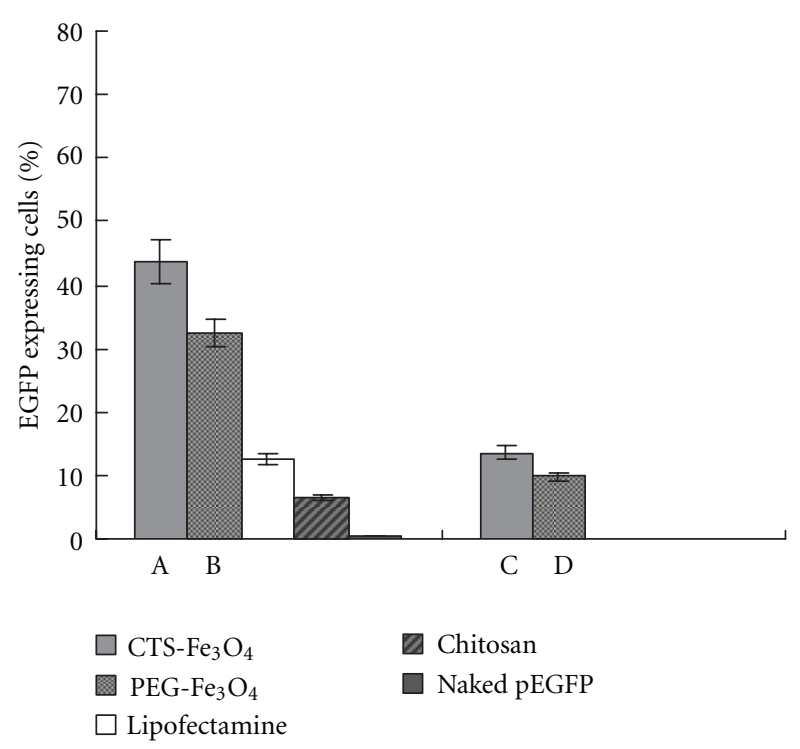

FIGURE 4: Magnet-assisted transfection of pEGFP plasmid. The $\mathrm{SP} 2 / 0$ cells were transfected with either polymer $\mathrm{Fe}_{3} \mathrm{O}_{4}$ or traditional transfection methods in the presence or absence of static magnetic field for $30 \mathrm{~min}$. A and B: magnet-assisted transfection; other groups: traditional transfection. Data are shown as means and $\mathrm{SD}$ values from at least three independent experiments $(P<0.01$ between $\mathrm{A}$ and $\mathrm{C}$; $\mathrm{B}$ and $\mathrm{D}$ ).

diseases. Thus, they were good representative samples for enhancement of delivery and effective targeting of gene expression. Furthermore, the EGFP expression was strong in transfected cells indicating that the function of DNA was kept and no fragmentation occurred.

Magnetic materials modified by biodegradable polymers as gene carriers possess many merits. For examples, simple manufacturing operation, arriving at the target point with the help of an outer magnetic field; a powerful surface energy effect and a small size effect are their outstanding characters. Moreover, it is easy to modify all kinds of multifunctional groups or targeting molecules to form the structure of the core shell, such as CTS, PEI, specific ligands, and monoclonal antibodies, since the complexes have multiple binding sites on their surface, and DNA attaches itself to them in sizeable amounts either through an electrostatic effect or by chemical bond coupling. In order to improve the E.E. of the polymer$\mathrm{Fe}_{3} \mathrm{O}_{4}$ complexes and realize the controlled release of the DNA, we modified the $\mathrm{Fe}_{3} \mathrm{O}_{4}$ with multifunctional groups CTS and PEG. In addition, the process of linking polymeric groups did not utilize organic solvent extraction, and the iron content used does not surpass the acceptable daily intake. Furthermore, some of the novel nanoparticles could improve the antigen presentation effect, show a better adjuvant effect, and make a long-term, single-immunization vaccine possible [23]. There are likely to be further applicative studies of polymer- $\mathrm{Fe}_{3} \mathrm{O}_{4}$ complexes as gene delivery systems. Preliminary data from our studies suggest that $\mathrm{Fe}_{3} \mathrm{O}_{4}$ nanoparticles when decorating with positive-charged polymer CTS exhibit preferential gene delivery.

\section{Conclusion}

CTS- $\mathrm{Fe}_{3} \mathrm{O}_{4}$ and PEG- $\mathrm{Fe}_{3} \mathrm{O}_{4}$ were successfully prepared. DNA encapsulation efficiency increased with the proportion of polymer- $\mathrm{Fe}_{3} \mathrm{O}_{4}$ nanoparticles, and the optimal E.E. $(3: 1)$ was chosen. Simultaneously, the attachment of DNA to polymer- $\mathrm{Fe}_{3} \mathrm{O}_{4}$ complexes did provide protection against cleavage by nuclease. The target distribution of polymer$\mathrm{Fe}_{3} \mathrm{O}_{4}$ complexes with an outer magnetic field was demonstrated in vivo. The controlled-release effect of CTS- $\mathrm{Fe}_{3} \mathrm{O}_{4}$ complexes was more apparent than PEG- $\mathrm{Fe}_{3} \mathrm{O}_{4}$, and the DNA binding and release from the polymer- $\mathrm{Fe}_{3} \mathrm{O}_{4}$ do not alter its functionality. Both CTS- $\mathrm{Fe}_{3} \mathrm{O}_{4}$ and PEG- $\mathrm{Fe}_{3} \mathrm{O}_{4}$ had low cytotoxicity to HEK-293 and HepG2 cells. The concentration of $2 \mathrm{mM}$ or less in an in vitro application was shown to be absolutely safe. In addition, the magnetic forces lead to an accelerated sedimentation of polymer- $\mathrm{Fe}_{3} \mathrm{O}_{4}$ complexes on the cell surface and do directly enhance the transfection efficiency in HepG2 and SP2/0 cells compared with conventional transfection methods. The novel gene delivery system proved to be an effective tool for future, and it is promising in targeting expression and delivery of therapeutic genes in in vivo studies. Our study explored the application of polymer- $\mathrm{Fe}_{3} \mathrm{O}_{4}$ nanoparticles as gene carriers. We will continue to do research in this field to provide a more detailed evaluation about the transfer of DNA.

\section{Conflict of Interests}

All of the authors have no conflict of interests.

\section{Acknowledgment}

The authors thank the financial support from National Natural Science Foundation of China (Grant no. 30901270).

\section{References}

[1] M. A. Mintzer and E. E. Simanek, "Nonviral vectors for gene delivery," Chemical Reviews, vol. 109, no. 2, pp. 259-302, 2009.

[2] U. Lungwitz, M. Breunig, T. Blunk, and A. Göpferich, "Polyethylenimine-based non-viral gene delivery systems," European Journal of Pharmaceutics and Biopharmaceutics, vol. 60, no. 2, pp. 247-266, 2005.

[3] W. Bing, Z. Shubiao, C. Shaohui et al., "Chitosan enhanced gene delivery of cationic liposome via non-covalent conjugation," Biotechnology Letters, vol. 34, pp. 19-28, 2012.

[4] S. Yang and S. May, "Release of cationic polymer-DNA complexes from the endosome: a theoretical investigation of the proton sponge hypothesis," Journal of Chemical Physics, vol. 129, no. 18, Article ID 185105, 2008.

[5] G. Wenjuan, C. K. L. James, and W. L. Solomon, "Functional enhancement of chitosan and nanoparticles in cell culture, tissue engineering, and pharmaceutical applications," Frontiers in Physiology, vol. 3, pp. 1-13, 2012.

[6] X. Wang, J. Yao, J. P. Zhou, Y. Lu, and W. Wang, "Synthesis and evaluation of chitosan-graft-polyethylenimine as a gene vector," Pharmazie, vol. 65, no. 8, pp. 572-579, 2010.

[7] P. Yu, Q. Wang, X. Zhang, X. Zhang, S. Shen, and Y. Wang, "Development of superparamagnetic high-magnetization 
C18-functionalized magnetic silica nanoparticles as sorbents for enrichment and determination of methylprednisolone in rat plasma by high performance liquid chromatography," Analytica Chimica Acta, vol. 678, no. 1, pp. 50-55, 2010.

[8] S. Hossein, H. Elham, S. Meisam, and K. Kevin, "Synthesis and characterization of core-shell Fe3O4-gold-chitosan nanostructure," Journal of Nanobiotechnology, vol. 10, no. 3, 2012.

[9] O. Mykhaylyk, Y. S. Antequera, D. Vlaskou, and C. Plank, "Generation of magnetic nonviral gene transfer agents and magnetofection in vitro," Nature Protocols, vol. 2, no. 10, pp. 2391-2411, 2007.

[10] E. P. Furlani and X. Xue, "A model for predicting fielddirected particle transport in the magnetofection process," Pharmaceutical Research, vol. 29, no. 5, pp. 1366-1379, 2012.

[11] J. Bertram, "MATra-magnet assisted transfection: combining nanotechnology and magnetic forces to improve intracellular delivery of nucleic acids," Current Pharmaceutical Biotechnology, vol. 7, no. 4, pp. 277-285, 2006.

[12] B. Castillo, L. Bromberg, X. López et al., "Intracellular delivery of siRNA by polycationic superparamagnetic nanoparticles," Journal of Drug Delivery, vol. 2012, pp. 1-12, 2012.

[13] J. Sun, S. Zhou, P. Hou et al., "Synthesis and characterization of biocompatible Fe3O4 nanoparticles," Journal of Biomedical Materials Research A, vol. 80, no. 2, pp. 333-341, 2007.

[14] X. Zhou, B. Liu, X. Yu et al., "Controlled release of PEI/DNA complexes from PLGA microspheres as a potent delivery system to enhance immune response to HIV vaccine DNA prime/MVA boost regime," European Journal of Pharmaceutics and Biopharmaceutics, vol. 68, no. 3, pp. 589-595, 2008.

[15] O. Veiseh, J. W. Gunn, and M. Zhang, "Design and fabrication of magnetic nanoparticles for targeted drug delivery and imaging," Advanced Drug Delivery Reviews, vol. 62, no. 3, pp. 284-304, 2010.

[16] C. He, Y. Hu, L. Yin, C. Tang, and C. Yin, "Effects of particle size and surface charge on cellular uptake and biodistribution of polymeric nanoparticles," Biomaterials, vol. 31, no. 13, pp. 3657-3666, 2010.

[17] M. C. Daniel, I. B. Tsvetkova, Z. T. Quinkert et al., "Role of surface charge density in nanoparticle-templated assembly of bromovirus protein cages," ACS Nano, vol. 4, no. 7, pp. 38533860, 2010.

[18] W. Weecharangsan, P. Opanasopit, T. Ngawhirunpat, T. Rojanarata, and A. Apirakaramwong, "Chitosan lactate as a nonviral gene delivery vector in COS-1 cells," AAPS PharmSciTech, vol. 7, no. 3, pp. E74-E79, 2006.

[19] H. B. Agashe, T. Dutta, M. Garg, and N. K. Jain, "Investigations on the toxicological profile of functionalized fifth-generation poly(propylene imine) dendrimer," Journal of Pharmacy and Pharmacology, vol. 58, no. 11, pp. 1491-1498, 2006.

[20] T. H. Chung, S. H. Wu, M. Yao et al., "The effect of surface charge on the uptake and biological function of mesoporous silica nanoparticles in 3T3-L1 cells and human mesenchymal stem cells," Biomaterials, vol. 28, no. 19, pp. 2959-2966, 2007.

[21] M. Huo, Y. Zhang, J. Zhou et al., "Synthesis and characterization of low-toxic amphiphilic chitosan derivatives and their application as micelle carrier for antitumor drug," International Journal of Pharmaceutics, vol. 394, no. 1-2, pp. 162-173, 2010.

[22] F. Alexis, E. Pridgen, L. K. Molnar, and O. C. Farokhzad, "Factors affecting the clearance and biodistribution of polymeric nanoparticles," Molecular Pharmaceutics, vol. 5, no. 4, pp. 505$515,2008$.
[23] R. C. Mundargi, V. R. Babu, V. Rangaswamy, P. Patel, and T. M. Aminabhavi, "Nano/micro technologies for delivering macromolecular therapeutics using poly(d,l-lactide-coglycolide) and its derivatives," Journal of Controlled Release, vol. 125, no. 3, pp. 193-209, 2008. 

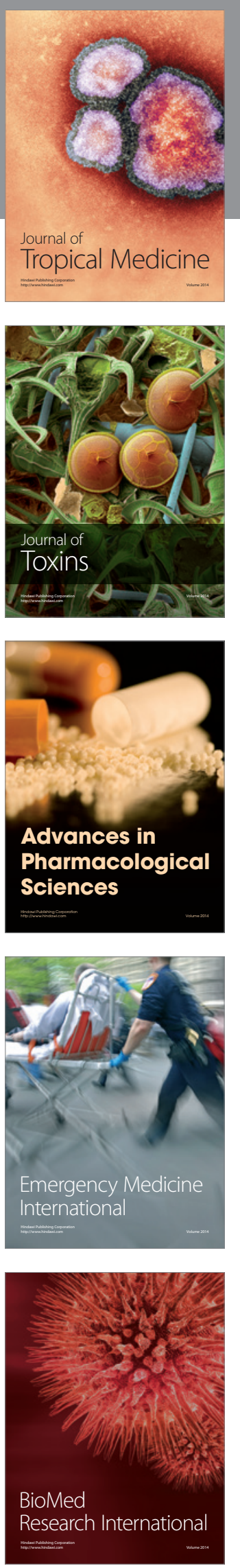
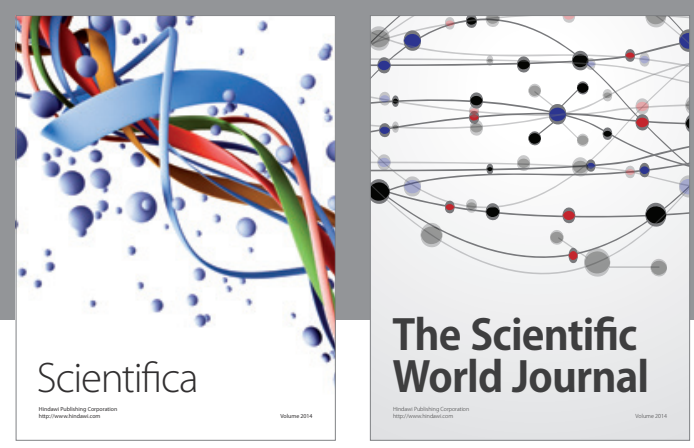

The Scientific World Journal
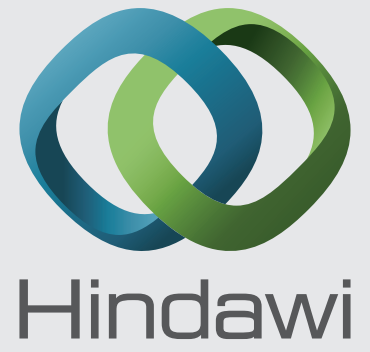

Submit your manuscripts at

http://www.hindawi.com
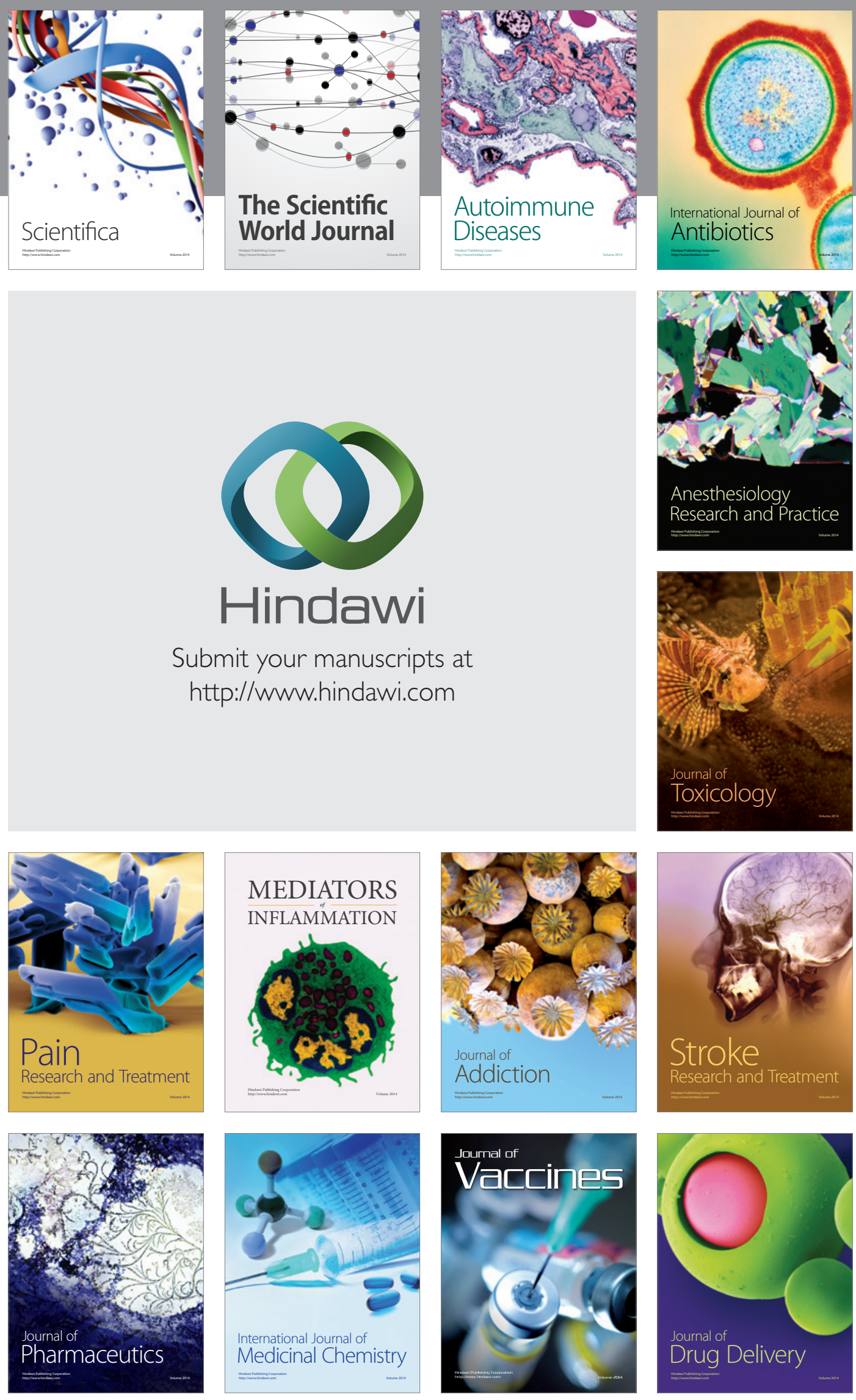